\title{
Implementation of Arabic Learning Based on Direct Method in Madrasah Kuttab Ibadurrahman
}

\author{
Asih Indartiwi \\ Maulana Malik Ibrahim Islamic State University Malang \\ Email: asihindartiwi1996@gmail.com \\ Romy Mukromah \\ Maulana Malik Ibrahim Islamic State University Malang \\ Email: romymukromah@gmail.com \\ Zakiyah Arifa \\ Maulana Malik Ibrahim Islamic State University Malang \\ Email: arifazakiyah@uin-malang.ac.id
}

\begin{abstract}
This study discusses the implementation of learning Arabic by using direct methods in practice. Implementation of learning includes several aspects, including opening lessons, delivering material, and closing lessons. In practice, the direct method of learning Arabic is strongly supported by the regulation of how learning can be realized by the expected results. This relates to learning done to students at the elementary level. In learning a foreign language, elementary students tend to be able to receive language quickly like Mother's tongue, but if taught as a child. The research method used is descriptive qualitative research instruments in the form of observation, interviews, and documentation. Then the data are analyzed by data reduction, data display, and verification. The results of this study are 1) the application of learning Arabic with the direct method is by the needs of students where the teacher is native from Libya. Therefore, Arabic is taught directly by native speakers so students can learn languages according to a fluent dialect, 2) the implementation of learning is said to have fulfilled the rules on aspects of the opening lesson, delivering material and closing lesson. However, learning that is carried out by the direct method still teaches in writing skills, whereas in essence, the direct method emphasizes more on listening and speaking skills.
\end{abstract}

Keywords: Implementation, Arabic Learning, Direct Method 


\section{Abstrak}

Penelitian ini membahas implementasi pembelajaran bahasa Arab dengan menggunakan metode langsung dalam praktik. Implementasi pembelajaran mencakup beberapa aspek termasuk membuka pelajaran, menyampaikan materi dan menutup pelajaran. Dalam prakteknya metode pembelajaran langsung bahasa Arab sangat didukung oleh peraturan tentang bagaimana pembelajaran dapat diwujudkan sesuai dengan hasil yang diharapkan. Ini berkaitan dengan pembelajaran yang dilakukan kepada siswa di tingkat dasar. Dalam belajar bahasa asing, siswa sekolah dasar cenderung dapat menerima bahasa dengan cepat seperti bahasa ibu, tetapi jika diajarkan sebagai seorang anak. Metode penelitian yang digunakan adalah instrumen penelitian deskriptif kualitatif dalam bentuk observasi, wawancara dan dokumentasi. Kemudian data dianalisis dengan reduksi data, penyajian data dan kesimpulan. Hasil dari penelitian ini adalah 1) penerapan pembelajaran bahasa Arab dengan metode langsung sesuai dengan kebutuhan siswa di mana guru tersebut berasal dari Libya. Oleh karena itu, bahasa Arab diajarkan langsung oleh penutur asli sehingga siswa dapat belajar bahasa sesuai dengan dialek yang fasih, 2) pelaksanaan pembelajaran dikatakan telah memenuhi aturan tentang aspek membuka pelajaran, menyampaikan materi dan menutup pelajaran. Namun, pembelajaran yang dilakukan dengan metode langsung masih mengajarkan keterampilan menulis, sedangkan pada dasarnya metode langsung lebih menekankan pada mendengarkan dan keterampilan berbicara.

\section{Kata kunci: Implementasi, Pembelajaran Bahasa Arab, Metode Langsung}

\section{Introduction}

Learning is essentially a process of interaction between the teacher and students, both direct interaction, such as face-to-face activities or indirectly, by using various media. Learning is the acquisition of knowledge about a subject or a skill by learning, experience, or instruction or a change in a person caused by experience. Learning also relates to the ability to manage learning components operationally and efficiently, to produce added value to these components based on applicable norms and standards. ${ }^{1}$

${ }^{1}$ Martinis Yamin dan Maisah, Manajemen Pembelajaran Kelas Strategi Meningkatkan Mutu Pembelajaran, (Jakarta: Gaung Persada, 2009). Hal. 165. 
The implementation of learning is a process that is arranged in such a way based on certain procedures so that the implementation reaches the expected results. These procedures include opening the lesson, delivering the material, and closing the material. The good management is needed that can support the achievement of learning objectives to provide the quality of learning. In this case, the teacher, as a manager in learning, the teacher's role as a manager in conducting learning is the process of mobilizing students to conduct learning activities in the context of behavior change (cognitive, affective, and psychomotor) towards maturity.

As a professional assignment, learning activities created by teachers should not be done haphazardly but should be managed as well as possible by the principles of learning and good learning management. Moreover, teaching and learning activities in schools is a very strategic thing as a systematic effort to achieve educational goals. Good management determines the pros and cons of learning, as a teacher uses appropriate methods, the provision of adequate learning tools, and a conducive classroom atmosphere when teaching and learning.

The manager directs management processes such as planning, organizing, directing, and controlling under his command, to achieve them as management objectives, with the highest efficiency. ${ }^{2}$ So that it can be seen that the role of management in a learning is an important element that needs to be considered as carefully as possible so that the learning process of Arabic can run effectively and efficiently.

To review in-depth management in learning Arabic can be seen in various aspects of learning activities, one of which is in the implementation aspect. So in this study, researchers want to focus on this. This research was conducted at the Madrasah Kuttab Ibadurrahman, which is the implementation of learning Arabic using the direct method. The direct method is a method that emphasizes the practice of consistent conversation between teachers and students using Arabic without the slightest use of Indonesian both in explaining vocabulary and translating. ${ }^{3}$ The direct method assumes that learning the good language is direct learning to use language taught intensively in communication so

${ }^{2}$ Ibrahim bin Abdul Aziz ad-Dailaj, al-Idarah al-Ammah wal Idarah at-Tarbawiyah. (Oman: Dar ar-Rawad, 2008). Hal. 10.

3 Wisnawati Loeis, "Metode Langsung Dalam Pembelajaran Bahasa Arab," Jurnal Turats, Vol. 7, No. 2, (2011): 26. 
that there is a direct interaction between educators and students using that language. Its use in class must be like a native speaker. ${ }^{4}$

The objects in this study are class 1 Madrasas, amounting to 21 people and students aged around 5-7 years. Which is the same age children tend to play actively. The direct method is best used for participants of this age because learning Arabic using such methods is the same as obtaining the mother tongue with learning done through the modeling and movement method ${ }^{5}$ Therefore researchers feel interested in researching the implementation of learning Arabic by direct methods in Madrasah Kuttab Ibadurrahman. From this arises the question 1) How is the method directly applied in the implementation of Arabic learning, 2) How does the teacher manage the implementation of Arabic learning.

\section{Methods}

The methodology used in this study is a qualitative (descriptivequalitative) description. Based on a qualitative approach, the report includes descriptive problems from the program or the experiences of people in the search environment. The purpose of this descriptive study is to help the reader know what is happening in the observation environment, such as how participants see the preparation of the research, and what events or activities occur within the research framework. ${ }^{6}$ The definition of the descriptive method is a method of analysis that focuses on sufficient and accurate information about a particular phenomenon or topic, or periods or periods that are known, to obtain scientific results, and then interpret them objectively, according to the actual data of the phenomenon. ${ }^{7}$

Data collection methods used in this study were: (1) Interview: We took the necessary information from the teacher at Kuttab Ibadurrahman. (2) Observation: We observe the process of Arabic language education in Kuttab Ibadurrahman directly. (3) Documentation: We take documents related to the Arabic education process, such as tables and figures.

${ }^{4}$ Abdul Hamid, Uril Baharuddin, dan Bisri Mustofa, Pembelajaran Bahasa Arab Pendekata, Metode, Strategi, Materi dan Media, (Malang: UIN Malang Press, 2008), Hal. 23.

${ }^{5}$ Abdurrahman bin Ibrahim Al-Fauzan, Idhaat li Muallimi al-Lughah al-Arabiyah li alNathiqin Biha, (Al-Riyadh: Maktabah Mamlakah, 2011). Hal. 80.

6 Emzir, Metodologi Penelitian Pendidikan: Kuantitaif dan Kualitatif, (Depok: RajaGrafindo, 2017). Hal. 174.

${ }^{7}$ Raja Wahid Darwidi, al-Bahts al-Ilmy Asasatuh an-Nazhariyah wa mumarastuhu al-Ilmyyah. (Beirut: Darul Fikr, tt). Hal. 183. 
The data analysis method used is the Miles and Huberman analysis method consisting of three steps, namely: (1) Data Reduction, is the researcher summarizes existing data, selects the main things, and focuses the data on Tasks, then deletes data unneeded. Data that has been reduced will provide a clear picture and make it easier for researchers to collect the following data, (2) Data Display is that the researcher displays the main and important data in the form of summaries, graphs, and the like. This stage is omitted to make it easier for researchers to understand the reality, and planning the following work based on what the researcher assumes, (3) Verification, is that the researcher concludes the data obtained and is verified by the researcher. ${ }^{8}$

\section{Application of the direct method}

The several elements of Arabic learning above, one of the most fundamental elements in learning, is the existence of a method. Several methods can be applied in learning, including the well-known method in learning foreign languages is the direct method.

The direct method is one of the effective methods used in learning foreign languages. Because during the learning process, educators directly use foreign languages that are taught, while the language of students should not be used. When there is a vocabulary that is difficult for students to understand and is needed to be translated into Indonesian, the educator explains the meaning by pointing to the objects in question, using movements, reenactments, photographs, and pictures.

Rohman explains the direct method aimed at teaching students to think in foreign languages without having to translate it first in a fast time because this method shows language by directly confronting students in environmental situations that can explain the meaning of vocabulary by connecting between formulas language with its purpose directly without intermediaries translating into Indonesian. ${ }^{9}$

The characteristics of the direct method are as follows ${ }^{10}$ :

1. The subject matter consists of words and sentence structures that are widely used every day.

${ }^{8}$ Sugiyono, Metode Penelitian Pendidikan (Pendekatan Kuantitatif, Kualitatif, dan $R \& D)$, (Bandung : Alfabeta, 2017). Hal. 338-345.

${ }^{9}$ Fathur Rohman, Metodologi Pembelajaran Bahasa Arab, Hal. 153. Hal. 61-62.

${ }^{10}$ Jos Daniel Parera, Linguistik Edukasional, Cet. I, (Jakarta: Penerbit Erlangga,1997), 
2. Gramatika is taught through situations and is done verbally, not by memorizing grammatical rules.

3. The concrete meaning is taught by using objects, while the abstract purpose is through association.

4. Many listening and mimicking exercises to achieve language acquisition can be completed automatically.

5. Oral grammar and vocabulary teaching.

6. Listen and mimic freely until the grammatical forms and vocabulary appear automatically.

7. Initially focused on speech

8. All reading material is presented orally.

As for the steps to apply the direct method of teaching a foreign language, in this case, Arabic, we need to look at the basic concepts of this method, as explained above. In general, the steps that must be taken are as follows: ${ }^{11}$

1. The introduction contains various matters relating to the material that will be presented either in the form of apperception, preliminary tests about the content, or others.

2. Educators provide material in the form of short dialogs that are relaxed, with language that is usually used every day repeatedly.

3. Learners are directed to discipline to listen to the dialogues but to imitate the conversations that are presented until smooth.

4. Students are guided to implement these dialogues with their friends in turns. Students who have advanced are given the opportunity to hold other conversations analogous to the examples given by educators.

5. The structure or grammar is given not by analyzing Nahwu, but by providing examples orally which draw attention to students to bring their own conclusions.

6. In closing, if needed, a final evaluation in the form of dialogue questions that must be answered by students as the patterns that have been made.

7. Aside from the steps mentioned above, educators can also create methods for their application by the situation and conditions in their

11 Acep Hermawan, Metodologi Pembelajaran Bahasa Arab, Cet. I, (Bandung: PT Remaja Rosdakarya, 2011). Hal. 89-90. 
schools, provided they do not conflict with the basic concept of this method.

Based on the results of observations, the Ihyaul Qur'an Foundation, founded by Ustadz Ahmad Jalaluddin, is an educational institution created based on the foundation of wanting to give birth to the generation of Qur'ani Ulul Albab who has Ahlussunnah Waljama'ah and his noble character. This foundation houses two levels of education, including kindergarten and Kuttab Ibadurrahman, which is housed in Perum M Regency No. 1 Tunggulwulung City of Malang. Kuttab Ibadurrahman is one level of basic knowledge which is equivalent to primary schools in general but in non-formal status. Kuttab Ibadurrahman has an Arabic language program that is collected in learning. The curriculum applied at Kuttab Ibadurrahman is more or less mirrored in the Kuttab Ibn Abbas curriculum. In the Kuttab Ibn Abbas curriculum there are three outlines designed including 1) Al-Quran, Memorizing and understanding the contents of the Koran, 2) Faith, Knowing and practicing the branches of faith (Syu'abulIman), 3) Ulum alWasail, Mathematics, Indonesian, Arabic, English, Science, and Social Sciences. But in this Kuttab Ibadurrahman curriculum that was created was to integrate al-Qur'an education and Arabic.

Because Kuttab Ibadurrahman has only been running for five months since June 2019, the number of students is only 21 people, and they still occupy the position of class 1 if it is equivalent to elementary school usually. The age of students ranges from 5-7 years. Arabic learning that is also made still focuses on language skills, including listening, reading, speaking, and writing. Learning Arabic in Kuttab Ibadurrahman is planned by inviting teachers from Libya. Thus Arabic is taught directly by native speakers so that they can practice the language skills of students. The method used in learning is the direct method where the teacher explains the material and interacts with students in Arabic.

Based on the application of the above method, it is in line with the basics of the direct method of learning using full Arabic without using mother tongue, and the teacher does not teach vocabulary and sentences except those widely used in daily life, communication is woven in the 
form of questions and answers between the teacher and students, inductive methods learn Nahwu, lesson points are conveyed orally. ${ }^{12}$

\section{The teacher's management in the implementation of Arabic learning}

The Learning Implementation is a process that is arranged in such a way according to specific steps so that the implementation reaches the expected results. The implementation of learning is an educational activity that contains interaction between teacher and student. Educative value interaction due to the implementation of learning carried out aims to achieve specific goals that have been formulated before the implementation of learning begins. In the implementation of learning, teachers do several stages of the implementation of learning, including :

a. Opening lessons

The activity of opening a lesson is an activity carried out by teachers to create an atmosphere of learning that aims to prepare students in their learning activities. In this activity, the teacher must pay attention to and meet the needs of students and show great concern for the existence of students.

Based on the results of observations, before starting the teacher's learning, first, open by saying of greeting. Then the teacher checks the attendance and readiness of students, such as asking for books and arranging students' sitting positions. When students are ready to learn, the teacher asks questions that have been learned before. Then the teacher continues learning with the next theme. In the learning process, the teacher also oversees student work, such as checking student books, checking student writing, and making students focus on learning material. Due to students who are still children, in the learning process, there are still other busy activities such as playing, running, and doing work that he likes. Therefore the teacher, besides giving a lesson, also provides directions for disciplining students in learning. The teacher also provides stimuli in the form of question and answer communication so that students can focus attention on the delivery of learning material. Therefore it is based on the basis and characteristics of the direct method applied in Arabic learning, including students playing an active role or talking

${ }^{12}$ Fathur Rohman, Metodologi Pembelajaran Bahasa Arab, (Malang: Madani, 2015). Hal. 154. 
more because of communication in the form of questions and answers by the teacher. ${ }^{13}$

In opening a lesson, several components can support the learning process to realize the conditions of students before learning so that their interests and mentality focus on what they are going to learn. These components include the following ${ }^{14}$ :

1) Attracting student's attention

In attracting student's attention, several things must be done by the teacher, namely choosing sound variations (high or low), varying the expression according to the topic of conversation, choosing positions (in front, in the middle, and behind) and choosing activities (reading, telling stories, demonstrations, open discussion forums).

In the implementation of learning, the teacher has carried out activities attracting the attention of students by practicing teaching styles. This can be seen from the variation of teaching teachers who choose high voices, so students are eager to learn, then the teacher also moves teaching positions from the front then to the center while looking at the work of students. It's just that more teachers are ahead. Then the teacher chooses to use learning activities with lecture-style through the direct method. The direct method of interaction that will occur also involves the activeness of students directly.

This is in line with the opinion of Halimah which states that teachers who are professional in managing the learning process are teachers who can apply teaching skills that are very basic such as skilled in asking, specialized in providing reinforcement, skilled in holding variations in learning, proficient in explaining and delivering material, qualified in opening and closing learning, skilled at leading discussions, skilled at managing classes, and skilled at teaching small groups and individuals. ${ }^{15}$

2) Using tools or learning media

${ }^{13}$ Fathur Rohman, Metodologi Pembelajaran Bahasa Arab, Hal. 154-155

14 Oktaviani dkk, "Keterampilan Membuka dan Menutup Pelajaran Pembelajaran Matematika, "Jurnal PAJAR (Pendidikan dan Pengajaran), Volume 3, Nomor 1 (Januari 2019): 47, diakses Tanggal 6 December 2019.

${ }^{15}$ Leli Halimah, 2017. Keterampilan Mengajar (Sebagai Inspirasi Untuk Menjadi Guru Yang Excellent di Abad Ke-21). Bandung: PT. Refika Aditama, Hal 97. 
The use of media in learning will help students focus their attention. Because basically, the press will describe abstract concepts to be more concrete. In the learning process, the press is needed to facilitate the delivery of information to students. The use of new media aims to invite students' curiosity about what will be learned. The use of media will also make students more focused attention on the learning material delivered.

The teacher does not use special media, but the teacher uses markers and blackboards. Thus, the teacher conveys learning by writing it on the board and then explaining it. When in the process, there are difficulties for students, the teacher analogs the material with the appropriate context or draws it on the board. This has proven to help students understand the purpose of what is explained.

This is consistent with the opinion of AECT, which says that the media is everything that is used to channel messages. ${ }^{16}$ Media can be in the form of hardware such as computers, LCD, televisions, and blackboards and can be in the form of the software contained in the equipment.

3) Perform variations in interaction patterns from various directions

Interaction in the learning process is needed to create a competent understanding from the teacher, can understand the development of student thinking, and students can understand what is conveyed by the teacher. In learning, the teacher must create interaction in the classroom. Interactions that occur can be in the form of teacher interactions with students, student interactions with teachers, and student interactions with other students.

The teacher has interacted well, the teacher explained all the subject matter, then the students listened, and there were a question and answer between the teacher and students and vice versa. Students also seemed to respond well to everything conveyed by the teacher. However, the interaction patterns that occur between students and students are not intertwined during the learning process, because learning is centered on the teacher

${ }^{16}$ Rudi Susilana Dan Cepi Riyana, Media Pembelajaran Hakikat, Pengembangan, Pemanfaatan, Dan Penilaian, (Bandung: CV Wacana Prima, 2009), Hal 6-7. 
and the method used by the teacher in teaching is a direct method, so there is no formation of learning groups for students.

Activities interacting with others is an activity that can foster cognitive conflict. Therefore, Piaget recommends that learners need to have the skills to foster cognitive conflict in the minds of learners.

4) Generating student motivation in learning activities

The teacher has an essential role in learning activities where the teacher can influence learning by providing motivation. So students have the enthusiasm to receive the learning to be given. In motivating students, some things can be done by the teacher, namely starting activities with passion, arousing students' curiosity, proposing conflicting ideas to attract students' interest in the subject matter, and paying attention to students' interests.

In the implementation of learning, real motivations have not yet been seen. But in its implementation, the teacher tries to provide a stimulus so that students can respond to learning well, and the teacher also provides an opportunity for students who know the purpose of the material to explain to other friends before the teacher explains it to students as a whole.

5) Provide a reference in starting learning activities

Reference in learning activities is given to limit the material to be delivered so that the material presented can be adapted to the learning context. The things that need to be done in providing a reference in learning are conveying the objectives and limits of the task, suggesting the steps to be discussed, reminding the main issues to be addressed, and asking questions.

In implementing learning, the materials are given in specific themes. For example, content about various vehicles, so when the teacher starts learning, first write the idea. Then the teacher mentions one by one the vocabulary about cars. The teacher then asks questions in opening learning.

6) Making links between activities 
Before the teacher starts to explain the material in detail or thoroughly, the teacher first conveys the relationships between events by explaining the concept and understanding. The teacher also links the material being studied with previous content and compares new knowledge with the knowledge that students already know. The things that must be done by the teacher are making connections between related aspects, comparing the new experience with known expertise, and expressing concepts to be conveyed.

The activity can be seen during the lesson that discusses the vocabulary of various vehicles, and the teacher first asks students to mention what are the types of cars before continuing the discussion about the purpose of each vocabulary.

b. Submission of material

The submission of learning material is the core of the process of implementing learning. In the delivery of material teachers deliver the following content from the most comfortable material first, using teaching methods that are appropriate to the material and use the media as aids to provide learning material, this is done so that it can maximize the acceptance of the students' elements in the order of the content delivered first. Also can realize the achievement of learning objectives that help students understand clearly all the problems in learning activities, help students to understand a concept or proposition, involve students to think, and follow the level of student understanding in receiving learning.

In presenting the material, the teacher uses the direct method, because this method aims to teach students to think in a foreign language without having to translate it in a fast time because this method teaches literature by directly confronting students in environmental situations that can explain the meaning of vocabulary in a way linking the formula of language with its purpose directly without the presence of intermediaries translated into Indonesian.

For the beginning of learning, primary students are given material about vocabulary. With the direct method applied by the teacher, making students more active. For example, before the teacher explains the meaning of vocabulary with the media, the teacher asks 
students the purpose of the vocabulary. Then students respond actively to answering questions from the teacher. After that, the teacher continues to the next vocabulary. The teacher explains the material using Arabic. The material presented in the form of primary material in Arabic is vocabulary. When students do not understand the meaning of vocabulary, the teacher gives an analogy that illustrates the vocabulary. Thus students can quickly understand the meaning of vocabulary that is not understood.

The tools used in learning are blackboards and markers. In the learning process, the teacher writes the material on the board and asks students to write what the teacher has written. The teacher also uses the tool as a medium when students have difficulty interpreting a vocabulary, so the teacher draws the vocabulary on the board.

The learning is carried out based on the practice of direct methods that explain that in giving meaning to abstract vocabulary, the purpose can be demonstrated or in the form of an analogy that relates to the minds of students. ${ }^{17}$

c. Closing lessons

Closing activities are activities conducted by the teacher to end these core activities in the learning process. In this activity, teachers undertake an evaluation of the material that has been delivered. The purpose of closing the lesson activities is to know the level of success of students in learning material, see the level of success of teachers in carrying out learning activities, and make a chain of competence between the content now and the content to come.

At the end of the lesson, it is essential to have a review of the learning material that has been delivered. This was done to emphasize the content to students so students could remember it actively. In reviewing learning, some essential things that must be done by the teacher are involving students in summarizing the core of the lesson, guiding students to make a summary, and requiring students to make conclusions.

Evaluation is done, aiming that the teacher can test students' understanding of the learning material that has been given. This can be done by providing questions, asking students to ask about stuff that is not yet understood, the teacher together with students

${ }^{17}$ Fathur Rohman, Metodologi Pembelajaran Bahasa Arab, Hal. 154-155. 
demonstrating the skills in the content, applying new ideas in other situations, asking students to express their opinions, and provide written exercises.

Based on the observations, in closing the lesson, the teacher asks the student worksheets that are asked to write what is written on the blackboard and then give a grade to the student's writing. Then the teacher gives the task to color the picture that aims to provide the brain with refreshes after learning and assigns the duty to continue the worksheet for students who have not completed it during the learning process.

Before closing the lesson, the teacher should do the following things :

1) Review

The teacher conducts a review activity by inviting all students to conclude the material that has been studied together. The teacher also encourages students to reach verbally.

2) Evaluation

The teacher conducts evaluation activities by giving questions to test students understanding and recalling material that has been learned. The items given are in the form of random problems using a game pattern or lottery. The teacher also always asks about content that is not yet understood. Furthermore, the teacher evaluates learning by asking students to show the written work instructed by the teacher to write it down.

This activity is not in line with the characteristics of learning that uses the direct method, because the direct method is more teaching listening and speaking skills, not teaching reading and writing skills. The direct method focuses more on the ability to speak Arabic because the basic form of language learning is speech. ${ }^{18}$

\section{Conclusions}

Based on some of the discussion above, it can be concluded that the implementation of Arabic learning in Kuttab Ibadurrahman is going well, because the implementation that is realized in learning is in

${ }^{18}$ Fathur Rohman, Metodologi Pembelajaran Bahasa Arab, Hal. 155. 
accordance with the learning objectives to be achieved, and learning has been adapted to the components that must be present in opening lessons and close the lesson. However, in the use of the direct method the teacher should place more emphasis on speaking skills because the purpose of learning with this method is as an exercise for students to think critically with the Arabic language they have learned without the need for translation into or from the mother tongue. Because like a child who learns mother tongue, then learning Arabic should use the direct method early on.

In this study, researchers can only raise the topic of how to manage an implementation of Arabic learning in elementary classes. The next researcher is expected to be able to complete this research by perfecting the discussion in terms of planning, organizing, mobilizing and evaluating.

\section{Bibliography}

ad-Dailaj, Ibrahim bin Abdul Aziz. 2008. al-Idarah al-Ammah wal Idarah atTarbawiyah. Oman: Dar ar-Rawad.

Al-Fauzan, Abdurrahman bin Ibrahim. 2011. Idhaat li Muallimi al-Lughah al-Arabiyah li al-Nathiqin biha. Al-Riyadh: Maktabah Mamlakah.

Darwidi, Raja Wahid. al-Bahts al-Ilmy Asasatuh an-Nazhariyah wa mumarastuhu al-Ilmyyah. Beirut: Darul Fikr.

Emzir. 2017. Metodologi Penelitian Pendidikan: Kuantitaif dan Kualitatif. Depok: RajaGrafindo.

Halimah, Leli. 2017. Keterampilan Mengajar (Sebagai Inspirasi untuk Menjadi Guru Yang Excellent di Abad Ke-21). Bandung: PT. Refika Aditama, Hal 97.

Hamid, Abdul dkk. 2008. Pembelajaran Bahasa Arab Pendekatan, Metode, Strategi, Materi dan Media. Malang: UIN Malang Press.

Hermawan, Acep. 2011. Metodologi Pembelajaran Bahasa Arab. Cet. I. Bandung: PT Remaja Rosdakarya.

Loeis, Wisnawati. 2011. “Metode Langsung Dalam Pembelajaran Bahasa Arab", Jurnal Turats, Vol. 7. No. 2.

Oktaviani dkk, "Keterampilan Membuka dan Menutup Pelajaran Pembelajaran Matematika, "Jurnal PAJAR (Pendidikan dan Pengajaran), Volume 3, Nomor 1 (Januari 2019): 47, diakses tanggal 6 Desember 2019. 
Parera, Jos Daniel. 1997. Linguistik Edukasional. Cet. I. Jakarta: Penerbit Erlangga.

Rohman, Fathur. 2015. Metodologi Pembelajaran Bahasa Arab. Malang : Madani.

Sugiyono. 2017. Metode Penelitian Pendidikan (Pendekatan Kuantitatif, Kualitatif, dan R\&D). Bandung : Alfabeta.

Yamin, martinis dan Maisah. 2009. Manajemen Pembelajaran Kelas Strategi Meningkatkan Mutu Pembelajaran. Jakarta: Gaung Persada (GP Press). 